\title{
PENGARUH FAKTOR KELUARGA TERHADAP PEMBELAJARAN REGULASI KENDIRI MURID SEKOLAH RENDAH
}

\section{INFLUENCE OF FAMILY FACTOR ON PRIMARY SCHOOL CHILDREN'S SELF-REGULATED LEARNING}

\section{Kanammah a/p Manukaram ${ }^{1}$, Melissa Ng Lee Yen Abdullah \& Shahizan Hasan \\ Pusat Pengajian Ilmu Pendidikan \\ Universiti Sains Malaysia}

${ }^{1}$ Corresponding author: kanammah1975@hotmail.com ${ }^{1}$

\begin{abstract}
ABSTRAK
Tujuan - Kajian ini dijalankan bertujuan untuk mengkaji pengaruh faktor keluarga dari segi gaya asuhan ibu bapa, suasana pembelajaran keluarga dan penglibatan keluarga dalam pembentukan kemahiran pembelajaran regulasi kendiri.

Metodologi - Kajian ini menggunakan kaedah tinjauan terhadap 639 orang murid Tahun 4 dan Tahun 5 dari 10 buah sekolah kebangsaan di Pulau Pinang. Teknik persampelan kelompok telah digunakan untuk memilih sampel tersebut. Kemahiran pembelajaran regulasi kendiri murid telah diukur dengan komponen kemahiran belajar dalam Motivated Strategies for Learning Questionnaire (MSLQ) manakala faktor keluarga diukur dengan Parental Authority Questionnaire, Family Environment Scale dan Perseption of Parents Scales (POPS).

Dapatan - Dapatan menunjukkan korelasi antara pembelajaran regulasi kendiri dengan dua faktor keluarga iaitu penyertaan ibu bapa dan orientasi pencapaian keluarga adalah positif dan berkekuatan sederhana. Pembelajaran regulasi kendiri murid sekolah rendah hanya mempunyai hubungan yang signifikan dengan gaya asuhan autoritatif dan autoritarian. Namun, hubungan antara variabel-variabel ini adalah lemah. Analisis regresi berganda stepwise pula menunjukkan bahawa faktor keluarga adalah peramal
\end{abstract}


pembelajaran regulasi kendiri yang signifikan iaitu penyertaan ibu bapa, orientasi pencapaian keluarga, sokongan ibu bapa, gaya asuhan tidak responsif dan gaya asuhan autoritatif. Secara keseluruhannya, keputusan analisis regresi berganda menunjukkan bahawa faktor keluarga menyumbang sebanyak 30.6\% (R2=.306) dalam pembelajaran regulasi kendiri murid sekolah rendah.

Kepentingan - Implikasi pendidikan dapatan kajian telah dibincangkan dalam kajian ini. Penglibatan keluarga, gaya asuhan ibu bapa dan suasana pembelajaran keluarga mempengaruhi pembelajaran regulasi kendiri. Faktor keluarga dapat membentuk murid yang mengawal atur strategi pembelajaran sejak kecil. Jadi, kajian ini menunjukkan bahawa ibu bapa mempunyai kesedaran tentang kepentingan pembelajaran regulasi kendiri sejak sekolah rendah.

Kata Kunci : Pembelajaran regulasi kendiri, penyertaaan ibu bapa, orientasi pencapaian keluarga, sokongan ibu bapa, gaya asuhan

\section{ABSTRACT}

Purpose - The purpose of this study was to determine the influence of family factors on primary school children's self-regulated learning. Specifically, parenting style, family learning orientation and parental involvement in developing self-regulated learning skill were examined.

Methodology - Quantitative survey was utilized to achieve the objectives of the study. The survey involved 639 Year 4 and 5 pupils from 10 primary schools located in the state of Penang. Cluster sampling technique was used to select the samples for this study. The pupils' self-regulated learning skills were measured with the Learning Strategy Scale taken from the Motivated Strategies for Learning Questionnaire (MSLQ), while family factor was measured using three instruments namely the Parental Authority Questionnaire, Family Environment Scale and Perception of Parents Scales (POPS).

Findings - Findings shows that self-regulated learning was positively correlated with parental involvement and family learning orientation. The strength of associations was considered moderate. The result implies that primary school pupils' self-regulated learning improves as parental participation and orientation towards 
achievement in the family increases. Self-regulated learning was also found to be significantly correlated with authoritative and authoritarian parenting styles. Nevertheless, the associations between the variables were rather weak. Stepwise regression analysis further showed that family factor was a significant predictor of self-regulated learning. As a whole, it explains 30.6\% (R2=.306) of the variance in self-regulated learning

Significance - The educational implications of the findings are discussed in this paper. Family involvement, parenting style and family learning environment influence self-regulated learning. Family factor will create the student who can control their learning strategy from young. Research shows that parents are aware of the importance of self-regulation of learning since primary school.

Keywords: Self-regulated learning, parental participation, family achievement orientation, parenting style

\section{PENGENALAN}

Pembelajaran regulasi kendiri atau self-regulated learning adalah definisi yang digunakan untuk menerangkan kemahiran seseorang murid mengawal atur sendiri proses pembelajarannya (Samsilah Roslan, 2000). Pembelajaran regulasi kendiri merupakan tingkah laku pembelajaran secara terarah kendiri yang dipersembahkan oleh pelajar melalui penggunaan strategi pembelajaran yang berbeza (Pintrich, 1999; Zimmerman, 1989a \& Zimmerman 1989b). Pembelajaran kendiri merupakan aspek penting pembelajaran murid dalam pencapaian akademik. Secara umumnya, ahli teori pembelajaran regulasi kendiri mengandaikan bahawa murid-murid berkemampuan untuk mempertingkatkan kemahiran pembelajaran mereka menerusi pemilihan dan penggunaan strategi-strategi metakognitif dan motivasi yang sesuai. Ahli teori pembelajaran regulasi kendiri juga mempercayai bahawa murid-murid memainkan peranan yang signifikan dalam menentukan kadar dan bentuk pengajaran yang diperlukan oleh mereka (Samsilah Roslan, 2000). Pembelajaran regulasi kendiri merupakan tingkah laku pembelajaran yang dijangka dapat dilatih melalui pengalaman sama ada melalui pendedahan kepada persekitaran atau kejayaan terdahulu. Pelaksanaan tingkah laku ini adalah atas kesedaran diri dan dipandukan oleh kepercayaan motivasi. Murid yang mempunyai 
kemahiran mengawal atur pembelajaran kurang menghadapi masalah pembelajaran. Hal ini kerana penyelidik mempercayai bahawa murid mampu menguasai dan mempelajari sesuatu sejak sekolah rendah. Jadi, tempoh masa pembelajaran di sekolah rendah memadai untuk melatih penggunaan strategi pembelajaran (Chris \& Rosemary, 2004). Zimmerman (1989a) juga menyokong bahawa pembelajaran regulasi kendiri sebagai kemahiran yang dijelmakan daripada kebolehan mental yang menekankan setiap individu mampu berfikir secara aktif tentang 'bagaimana', 'apa' dan 'bila' strategi pembelajaran yang digunakan, bertindak secara aktif untuk melaksanakan hasil fikiran mereka sehingga mencapai kejayaan yang diingini.

Untuk menentukan sama ada seseorang pelajar itu mengamalkan pembelajaran regulasi kendiri atau tidak, penyelidik (Pintrich, 2004; Zimmerman, 2002) meneliti tiga ciri utama; pertamanya, pelajar harus berperanan sebagai 'pembina' dan bukan semata-mata 'penerima' ilmu. Hal ini bermakna pembelajaran merupakan proses aktif yang dijana oleh pelajar sendiri. Kedua, pelajar mengawal faktor yang mempengaruhi kejayaan pembelajarannya, misalnya faktor persekitaran, serta faktor motivasi dan tingkah laku diri. Ketiga, tindakan pelajar adalah berasaskan matlamat yang jelas dan terarah. Pembelajaran berpandukan matlamat yang spesifik yang telah ditentukan mengikut hasrat individu. Pintrich (1999) mendapati individu yang aktif bukan sahaja menggunakan pelbagai strategi kognitif dan metakognitif tetapi juga dapat menguruskan sumber pembelajarannya secara berkesan. Murid yang berkemahiran tinggi dalam pembelajaran regulasi kendiri tidak bergantung sepenuhnya pada guru dalam proses pembelajaran. Mereka mampu mencari jalan penyelesaian untuk meningkatkan pemahaman diri serta mengatasi masalah pembelajaran yang dihadapi. Namun, kemahiran ini perlu dipupuk dan diperteguhkan oleh ibu bapa sejak dari peringkat awal lagi. Hal ini selaras dengan Teori Kognitif Sosial (Bandura, 1977 ; 1986) yang menganjurkan bahawa faktor persekitaran sosial memberi kesan terhadap pembentukan pembelajaran regulasi kendiri. Pemupukan kemahiran pembelajaran regulasi kendiri dalam kalangan kanak-kanak hendaklah dimulakan di peringkat awal lagi. Kajian lepas menunjukkan bahawa kanak-kanak memerlukan bimbingan dan dorongan orang dewasa untuk menguasai kemahiran pembelajaran regulasi kendiri (Chris \& Rosemary 2004). Rajah 1 menunjukkan kerangka kajian ini yang berlandaskan Model Pembelajaran Regulasi Kendiri Pintrich (1999) dan Teori Kognitif Sosial (Bandura, 1986). 


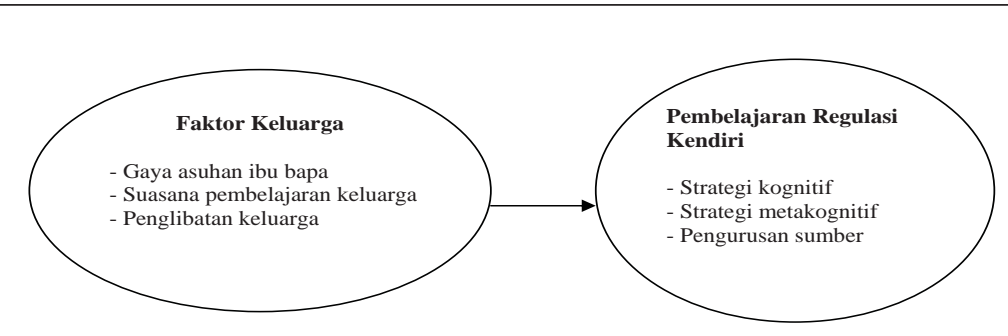

Rajah 1. Hubungan antara Faktor Keluarga dan Pembelajaran Regulasi Kendiri (Pintrich, 1999; Bandura, 1986).

\section{FAKTOR KELUARGA DAN PEMBELAJARAN REGULASI KENDIRI}

Tinjauan kajian-kajian lepas menunjukkan bahawa faktor keluarga mungkin boleh memberi kesan terhadap pembelajaran regulasi kanak-kanak dari segi gaya asuhan ibu bapa, suasana pembelajaran keluarga dan penglibatan keluarga dalam proses pembelajaran anak-anak.

\section{GAYA ASUHAN IBU BAPA}

Gaya asuhan ibu bapa dalam mendidik anak-anak mungkin akan melahirkan anak yang boleh memikul tanggungjawab di rumah. Sebenarnya sifat-sifat menguruskan diri sendiri perlu dilatih, dididik dan dipupuk sejak anak kecil lagi. Sifat ini tidak akan timbul secara 'semula jadi' (Mok, 2009). Ibu bapa harus meluangkan masa dan tenaga untuk melatih dan menyemai tabiat ini. Ibu bapa hendaklah memberikan pujian dan rangsangan setiap kali dia melakukannya dengan baik, atau menunjukkan usaha yang diingini.

Faktor persekitaran keluarga mempengaruhi gaya asuhan ibu bapa dalam keluarga. Gaya asuhan secara autokratik yang terlalu mengongkong kanak-kanak boleh menyebabkan mereka berasa terkongkong atau terpenjara, takut dan tidak berupaya membuat keputusan sendiri atau berdikari. Sebaliknya, gaya asuhan permisif menyebabkan kanak-kanak terumbang-ambing tanpa garis panduan dan tidak mempunyai disiplin. Gaya asuhan demokratik 
pula menggalakkan kanak-kanak mempunyai disiplin, berdikari, mengawal atur pembelajaran dan boleh membuat keputusan sendiri (Rohaty Mohd Majzub, T. Subahan Mohd Meerah Ahmad, \& Jaffni Hassan, 1994). Hal ini menunjukkan gaya asuhan dapat mempengaruhi strategi pembelajaran kanak-kanak kerana mereka meniru tingkah laku ahli-ahli keluarga yang menjadi contoh teladan kepada mereka. Dapatan kajian Rohaty et al., (1994) mempunyai persamaan dengan Baumrind (1971; 1991) dan Ng (2007b) yang mencadangkan empat jenis gaya asuhan, iaitu autoritatif, autoritarian, permisif dan tidak responsif.

Sorotan kajian menunjukkan gaya asuhan ibu bapa autoritatif adalah lebih sesuai diamalkan dan mempengaruhi perkembangan pembelajaran regulasi kendiri (Baumrind, 1971; 1991). Gaya asuhan ibu bapa dapat melahirkan anak-anak yang berdikari dan lebih bermotivasi serta mampu mengawal atur pembelajaran sendiri. Hasil kajian mendapati gaya asuhan ibu bapa autoritatif (authoritative) dapat membentuk pembelajaran regulasi kendiri. Hal ini kerana mereka sering melakukan aktiviti bersama, berkongsi idea, memberikan keyakinan, dan kasih sayang. Ibu bapa mereka saling memberikan sokongan dan kepercayaan, galakan, kurang mengongkong dan sering dapat memenangi hati mereka. Dalam pada itu, kajian Ensminger dan Slu Sarcik (1992), Huang dan Prochner (2004), Kanammah dan Ng (2009) dan Amy (1998) menunjukkan gaya asuhan ibu bapa dan sokongan keluarga dengan pihak sekolah mempunyai pengaruh yang amat tinggi terhadap strategi pembelajaran anak-anak. Murid daripada keluarga yang mempunyai peraturan ketat terhadap kerja sekolah di rumah, dilaporkan mempunyai pembelajaran regulasi kendiri yang tinggi kerana ibu bapa tidak begitu tegas dan penyayang. Hasil kajian Kanammah dan $\mathrm{Ng}$ (2009), ibu bapa berpendapatan tinggi lebih menunjukkan gaya asuhan ibu bapa autoritatif dan gaya asuhan permisif manakala ibu bapa berpendapatan rendah akan menghadapi kekurangan sumber kewangan, masa dan pengetahuan untuk mendidik supaya anak-anak mengamalkan gaya asuhan ibu bapa autoritarian dan tidak responsif. Hasil kajian juga menunjukkan bahawa murid yang mempunyai pengalaman gaya asuhan tidak responsif masih menunjukkan tingkah laku pembelajaran regulasi kendiri kerana mereka cekap mengatur strategi pembelajaran di samping mempunyai matlamat dalam kehidupan harian. Di samping itu, kajian Amy (1998) tentang kesan faktor keluarga terhadap pembelajaran regulasi kendiri 
dalam kalangan pelajar menunjukkan bagaimana gaya asuhan ibu bapa mempengaruhi pembelajaran regulasi kendiri. Hasil kajian menunjukkan gaya asuhan ibu bapa mempunyai perkaitan langsung dengan pembelajaran. Seterusnya, sokongan ibu bapa mempunyai hubungan positif terhadap anak-anak. Gaya asuhan ibu bapa juga mempengaruhi strategi pembelajaran anak-anak dari segi orientasi matlamat dan orientasi pencapaian akademik. Tuntasnya, kajiankajian lepas secara konsisten menunjukkan bahawa gaya asuhan ibu bapa secara langsung mempunyai hubungan dengan pembentukan pembelajaran anak-anak.

\section{SUASANA PEMBELAJARAN KELUARGA}

Suasana rumah yang mesra dan harmonis adalah menggalakkan bagi perkembangan tingkah laku yang sihat. Keadaan keluarga, sekolah, rakan sebaya, masyarakat dan pengalamannya mempengaruhi pembentukan dan perkembangan tingkah laku seseorang (Mok, 2009).

Kajian Amnon Lazar, Joseph Guttmann dan Liat Abas (2007), Ashley (2006), Dzulkarnain Haji Abdul Rahman (2003), Hashami Bohari, Ezaddin Mohamed Osman Ali dan Mohd Amin Sharif (1994), Marjoribanks (1994), Zarinah Arshat (2001), menunjukkan suasana keluarga penting bagi menentukan pembelajaran. Dapatan kajian menunjukkan bahawa pembentukan dan perkembangan tingkah laku seseorang bermula daripada suasana keluarga. Keadaan rumah yang harmonis dan perhubungan ibu bapa dengan anak-anak mereka erat serta mesra akan menggalakkan perkembangan tingkah laku yang positif seperti berdikari. Hal ini menunjukkan suasana pembelajaran keluarga mempengaruhi tingkah laku pembelajaran anak-anak. Kajian yang dijalankan oleh Zarinah Arshat (2001) bertujuan untuk menentukan kualiti persekitaran sosial keluarga dan perkaitannya dengan pembelajaran anak. Hasil kajian mendapati majoriti (94.2\%) responden memperoleh skor kualiti persekitaran sosial keluarga yang tinggi. Hasil analisis korelasi Pearson menunjukkan terdapat perkaitan signifikan $(\mathrm{r}=-0.18, \mathrm{p} \leq 0.05)$ antara kualiti persekitaran sosial keluarga dengan tahap pembelajaran anak. Kajian Zarinah Arshat (2001) merumuskan bahawa suasana pembelajaran keluarga mempunyai perkaitan dengan pencapaian akademik anak. Dalam pada itu, kajian Hashami Bohari, Ezaddin Mohamed Osman Ali 
dan Mohd Amin Sharif (1994) menggunakan ujian korelasi untuk mengenal pasti hubungan antara faktor status keluarga, jantina, tahap persekolahan dan pendapatan keluarga dengan tingkah laku pembelajaran. Dapatan kajian menunjukkan bahawa suasana pembelajaran keluarga memainkan peranan penting dalam kalangan anak dari keluarga bercerai. Hasil kajian ini merumuskan bahawa suasana pembelajaran keluarga, jantina, pendapatan keluarga mempunyai hubungan signifikan dengan strategi pembelajaran anak. Di samping itu, hasil kajian Dzulkarnain Haji Abdul Rahman (2003) menunjukkan terdapat pengaruh suasana pembelajaran keluarga terhadap strategi pembelajaran dan merupakan pemboleh ubah yang mencorakkan tingkah laku positif atau negatif. Suasana pembelajaran keluarga amat mempengaruhi budaya kendiri murid dalam sesebuah keluarga. Dapatan menunjukkan ibu bapa atau penjaga daripada keluarga tidak bermasalah memberi galakan untuk belajar dan lebih menekankan keperluan akademik berbanding dengan ibu bapa atau penjaga keluarga. Hal ini menunjukkan ibu bapa berperanan dalam memupuk pembelajaran (Dzulkarnain Haji Abdul Rahman, 2003). Selain itu, hasil kajian Ashley (2006) menunjukkan bahawa suasana pembelajaran keluarga yang harmonis dapat mewujudkan pembelajaran yang positif. Hasil kajian ini juga mendapati bahawa individu daripada suasana pembelajaran yang harmonis menunjukkan kesan yang positif dalam pembelajaran. Kajian ini bukan sahaja membantu untuk menambah pengetahuan tentang perhubungan ibu bapa dan anak, malah lebih menggambarkan pengaruh orientasi pencapaian keluarga dalam meningkatkan strategi pembelajaran anak-anak. Kajian Amnon Lazar, Joseph Guttmann dan Liat Abas (2007) menunjukkan suasana pembelajaran keluarga mempengaruhi strategi pembelajaran anak. Hasil analisis regresi berganda menunjukkan suasana pembelajaran keluarga berpengaruh terhadap strategi pembelajaran kanak-kanak. Dapatan kajian menunjukkan strategi pembelajaran anak dipengaruhi oleh suasana pembelajaran keluarga. Dapatan ini selari dengan pendapat Menurut Murugiah (1997), pula perhubungan yang baik antara ibu bapa dengan anakanak dapat menjamin suasana pembelajaran di rumah yang tenteram, mesra dan harmonis. Suasana pembelajaran keluarga memberi kesan terhadap pelajar-pelajar yang berasal daripada keluarga yang berpendapatan tinggi atau berstatus sosioekonomi tinggi. Dapatan kajian-kajian lepas menunjukkan suasana pembelajaran keluarga memberikan kesan terhadap pembelajaran anak-anak. 


\section{PENGLIBATAN KELUARGA}

Sorotan kajian Brody, Flor dan Gibson (1999), Christa et al., (2007), Milkie, Mattingly, Nomaguchi, Bianch, dan Robinson, (2004) Steinberg (1996) menunjukkan bahawa penglibatan keluarga mempengaruhi tingkah laku pembelajaran anak-anak.

Christa et al., (2007) telah mengkaji tentang model penyertaan ibu bapa terhadap 853 ibu bapa murid gred 6 dengan menggunakan pendekatan kualitatif. Ibu bapa mempunyai kepercayaan motivasi tentang penglibatan mereka dalam kehidupan anak-anak. Analisis keputusan menunjukkan bahawa terdapat signifikan dalam penyertaan ibu bapa apabila mengawal status sosioekonomi keluarga dalam ramalan pembinaan model penglibatan ibu bapa. Menurut Steinberg (1996) ibu bapa yang menunjukkan sikap positif dan mengambil berat boleh meningkatkan prestasi anakanak. Hasil kajiannya ke atas 20,000 orang sampel, mendapati pembelajaran pelajar di sekolah banyak dipengaruhi oleh peranan ibu bapa seperti membantu memeriksa kerja rumah serta memberi semangat dan kata-kata nasihat. Kajian Chris dan Rosemary (2004) juga menunjukkan bahawa penyertaan, sokongan ibu bapa dan penyediaan bahan pembelajaran yang sesuai dapat meningkatkan kemampuan belajar sendiri dalam kalangan murid Tahun 1, 2, dan 3. Mereka juga mempunyai tahap pembelajaran regulasi kendiri yang tinggi walaupun terdapat pandangan yang bertentangan tentang kemampuan kanak-kanak untuk menetapkan pembelajaran mereka sendiri pada peringkat umur yang rendah. Kajian Brody, Flor dan Gibson (1999), Milkie, Mattingly, Nomaguchi, Bianch, dan Robinson, (2004) menyatakan bahawa penyertaan ibu bapa mempunyai hubungan positif dengan tingkah laku pembelajaran. Perilaku sikap ibu bapa yang positif menjadi faktor perlindungan terhadap pembelajaran regulasi kendiri. Hasil kajian menunjukkan perkembangan dan tabiat pembelajaran anak-anak adalah lebih baik apabila ibu bapa mereka terlibat secara aktif dan berterusan dalam pendidikan mereka sejak awal lagi iaitu peringkat sekolah rendah. Penyertaan aktif dan sokongan ibu bapa di peringkat ini akan dapat meningkatkan potensi pembelajaran anak-anak melalui penerusan kaedah pembelajaran tersebut di rumah. Hasil kajian Milkie et al., (2004) pula menunjukkan bahawa ibu bapa banyak meluangkan masa bersama dengan anak-anak supaya mereka dapat mengawal atur pembelajaran. Misalnya, masa yang diluangkan adalah untuk 
mengajar, memeriksa kerja sekolah di rumah dan menjalankan aktiviti bersama anak-anak. Secara langsung penyertaan ibu bapa mempengaruhi strategi pembelajaran.

Rumusannya, penyertaan ibu bapa juga mempunyai hubungan signifikan terhadap pembelajaran anak-anak. Ibu bapa merupakan orang pertama yang mendidik dan melatih anak-anak di rumah sejak kecil. Dapatan-dapatan kajian menunjukkan faktor keluarga seperti gaya asuhan ibu bapa, suasana pembelajaran keluarga dan penglibatan keluarga mempengaruhi pembelajaran anak-anak dan mempunyai hubungan signifikan terhadap pembelajaran. Faktor keluarga memainkan peranan penting dalam pembentukan peribadi anak-anak kerana apabila kanak-kanak melangkah ke alam persekolahan, mereka membawa bersama mereka Curriculum of The Home yang mempengaruhi cara pembelajaran mereka di sekolah (Ballantine, 1997). Curriculum of The Home termasuklah suasana pembelajaran keluarga, bahan bacaan di rumah, perhatian ibu bapa terhadap kerja rumah, penglibatan ibu bapa dan punca kewangan keluarga.

\section{PERNYATAAN MASALAH}

Tinjauan ke atas kajian lepas menunjukkan bahawa kekurangan penyelidikan empirikal yang meneliti pengaruh faktor keluarga dalam pembelajaran regulasi kendiri maka sumbangan sebenar faktor tersebut belum dapat dipastikan, khususnya dalam konteks tempatan. Untuk menjadi pelajar yang cekap, murid-murid sebenarnya memerlukan kemahiran pembelajaran regulasi kendiri. Kemahiran ini perlu dipupuk dan diperkukuhkan sebaik sahaja murid memasuki sistem pendidikan formal. Hal ini bermakna faktor keluarga mungkin berperanan penting dalam pembelajaran regulasi kendiri di peringkat awal. Selain itu, kebanyakan kajian tentang pembelajaran regulasi kendiri bertumpu pada peringkat sekolah menengah dan universititi. Misalnya, kajian Premavathy (2005) dan Samsilah Roslan (2000) adalah berkaitan dengan sekolah menengah dan universiti. Justeru, pembelajaran regulasi kendiri murid sekolah rendah dan peranan keluarga pada peringkat tersebut masih belum diterokai. Sementara itu, dalam sistem pendidikan yang berorientasikan peperiksaan murid-murid sekolah lazimnya bergantung kepada guru untuk mencapai pencapaian akademik yang 
baik. (Abdullah, 2010a). Gaya pembelajaran yang berpusatkan guru dan spoon feeding sedemikian adalah amalan biasa di peringkat sekolah rendah dan menengah (Syed Anwar \& Merza Abbas, 2000). Akibatnya, kebanyakan -murid sekolah tidak bersedia untuk berdikari dalam proses pembelajaran. Mereka jarang dilatih untuk mencari bahan pembelajaran sendiri kerana bergantung kepada guru untuk merancang apa, bila, dan bagaimana untuk belajar (Syed Anwar \& Merza Abbas, 2000). Kajian ini penting kerana berpotensi untuk membantu pihak sekolah dan para pendidik merangka strategi untuk membantu murid sekolah meningkatkan kemahiran pembelajaran regulasi kendiri. Dua objektif kajian telah dibentuk untuk meneroka pengaruh faktor keluarga dalam pembelajaran regulasi kendiri murid sekolah rendah.

\section{OBJEKTIF KAJIAN}

Objektif kajian yang dikenal pasti adalah seperti berikut;

1. Mengkaji hubungan antara faktor keluarga dengan pembelajaran regulasi kendiri murid sekolah rendah.

2. Mengkaji pengaruh faktor keluarga (gaya asuhan ibu bapa, suasana pembelajaran keluarga dan penglibatan keluarga) terhadap pembelajaran regulasi kendiri murid sekolah rendah.

\section{METODOLOGI KAJIAN}

Kajian ini menggunakan pendekatan kuantitatif. Sampel kajian terdiri daripada 639 orang murid sekolah rendah iaitu murid Tahun Empat dan Tahun Lima dari 10 buah sekolah kebangsaan. Rasional memilih sampel ini ialah sampel darjah 4 dan 5 berada pada tahap yang sama iaitu Tahap 2 dan (tahap konkrit) (Ng, 2007b). Fokus kajian ini adalah berdasarkan model yang telah diubah dan pengukuran pembelajaran regulasi kendiri murid-murid adalah berdasarkan Model Pintrich, Smith, Garcia dan Mckeachie (1991). Selain itu, murid sekolah kebangsaan tidak mempunyai masalah pemahaman bahasa terutamanya bahasa Malaysia. Batasan seterusnya dalam kajian ini ialah instrumen soal selidik yang digunakan oleh penyelidik merupakan laporan tinjauan diri yang berdasarkan maklum balas yang diberikan oleh murid berdasarkan skala likert. 
Seterusnya, kajian ini lebih berfokuskan pengaruh faktor keluarga terhadap pembelajaran regulasi kendiri dalam kalangan murid sekolah rendah. Faktor lain seperti peranan guru, pihak sekolah, dan masyarakat tidak dikaji kerana kajian lebih menjurus kepada faktor keluarga dan strategi pembelajaran. Kaedah persampelan yang digunakan ialah persampelan kelompok. Persampelan kelompok digunakan adalah proses mengambil atau menggunakan sampel bila mana unit persampelan bukan lagi unsur dari populasi tetapi unsur dari kelompok populasi. Persampelan satu kelompok dari senarai kelompok yang telah dikenal pasti boleh dilakukan secara rawak dengan menggunakan Jadual Nombor Rawak (Mohd. Majid Konting, 1990). Faktor keluarga yang dikaji ialah gaya asuhan ibu bapa, suasana pembelajaran keluarga dan penglibatan keluarga. Instrumen terdiri daripada Bahagian A iaitu profil murid. Bahagian B terdiri daripada soal selidik Strategi Pembelajaran Regulasi Kendiri (SPRK) yang merangkumi 10 item untuk mengukur tahap pembelajaran regulasi kendiri dalam kalangan murid-murid sekolah rendah. Instrumen SPRK telah diterjemahkan dan diubahsuai daripada inventri Motivated Strategies for Learning Questionnaire (MSLQ) (Pintrich, 1999 \& Zimmerman, 1989b). Item-item item ini diadaptasi daripada kajian Ng (2007b) dan Samsilah Roslan (2000). Bahagian C (15 item) merangkumi kenyataan gaya asuhan ibu bapa ( gaya asuhan autoritatif, autoritarian, permisif dan tidak responsif) diukur dengan instrumen Parental Authority Questionnaire (Buri, 1991). Bahagian D (12 item) mempunyai kenyataan suasana pembelajaran keluarga (orientasi pencapaian keluarga dan orientasi intelektual budaya) diukur dengan instrumen Family Environment Scale (Moos \& Moos, 1974) manakala Bahagian E (10 item) pula merangkumi kenyataan penglibatan keluarga (penyertaan ibu bapa dan sokongan ibu bapa) diukur dengan instrumen Perseption of Parents Scales (POPS) (Grolilnick, Ryan \& Deci, 1991). Jumlah item secara keseluruhannya ialah 47 item. Dapatan kajian rintis menunjukkan bahawa Murid Tahun 4 dan 5 mampu menjawab kesemua item tersebut.

Kajian rintis telah dijalankan terhadap 100 orang murid sekolah rendah di Seberang Perai Utara untuk menentukan kesahan instrumen kajian. Menurut Sheridan, Lyndall dan Clara (2010) nilai signifikan melebihi 0.5 boleh diandaikan data bertaburan normal. Nilai alpha cronbach yang diperoleh bagi setiap konstruk adalah antara julat indeks 0.7 hingga 0.8 . Indeks kebolehpercayaan 
ini adalah tinggi dan boleh diterima pakai (Uma Sekaran, 2003). Keputusan kajian rintis kedua telah diperoleh setelah dijalankan tranformasi data untuk melihat kesahan soal selidik bagi setiap variabel yang dikaji (Sheridan, Lyndall \& Clara, 2010). Nilai kebolehpercayaan untuk pembelajaran regulasi kendiri (0.77), gaya asuhan ibu bapa (0.84), suasana pembelajaran keluarga (0.87), penglibatan keluarga (0.85). Kesahan item soal selidik penting untuk menjamin kualiti kajian. Gay dan Airasian (2003) juga menyatakan bahawa untuk menentukan kesahan kandungan instrumen, item perlu dibentuk dan dinilai oleh panel yang terdiri daripada responden berada di situasi sebenar kajian ini. Item yang diadaptasi oleh penyelidik dinilai lima orang panel pakar yang terdiri daripada seorang pensyarah berpengalaman dalam bidang psikologi pendidikan dari Universiti Sains Malaysia dan tiga orang panel dari Institut Pendidikan Guru Malaysia, Kampus Pulau Pinang untuk menilai kesahan kandungan item. Di samping itu, kesesuaian penggunaan bahasa dinilai oleh seorang pakar Bahasa Malaysia yang terdiri daripada guru sekolah rendah yang berpengalaman dan mempunyai pengkhususan Bahasa Malaysia dan lebih memahami tahap pemahaman murid sekolah rendah. Hasil keputusan kesahan kandungan oleh pakar dan hasil kajian rintis menunjukkan soal selidik ini mempunyai nilai kebolehpercayaan yang tinggi dan boleh diguna pakai dalam konteks Malaysia. Beberapa pengubahsuaian daripada segi kandungan bahasa telah dilakukan atas nasihat pakar kesahan kandungan. Pentadbiran dan pungutan data dalam kajian dijalankan dengan menggunakan kaedah kuantitatif. Untuk memastikan proses pentadbiran dan pungutan data berjalan lancar semasa ujian sebenar, maka ujian rintis dijalankan. Surat kebenaran juga diperoleh daripada Bahagian Perancangan dan Penyelidikan Pendidikan, Kementerian Pelajaran Malaysia, Jabatan Pelajaran Negeri (JPN), Pusat Pengajian Ilmu Pendidikan, Universiti Sains Malaysia. Data dianalisis dengan menggunakan analisis deskriptif dan inferensi. Penapisan data kajian seperti ujian kenormalan telah dijalankan sebelum analisis statitikal inferens dijalankan (Sharifah Amnah Syed Ahmad, 2008).

\section{DAPATAN KAJIAN}

Analisis korelasi Pearson digunakan untuk mengkaji hubungan pembelajaran regulasi kendiri dengan faktor keluarga. Keputusan analisis korelasi ditunjukkan pada Jadual 1. 
Jadual 1

Analisis Korelasi Faktor Keluarga dengan Pembelajaran Regulasi Kendiri

\section{Pembelajaran Regulasi Kendiri}

\begin{tabular}{lc}
\hline & Nilai korelasi $(r)$ \\
\hline Faktor keluarga & \\
Gaya asuhan ibu bapa & -.01 \\
Gaya asuhan tidak responsif & $.26^{* *}$ \\
Gaya asuhan autoritatif & $.21^{* *}$ \\
Gaya asuhan autoritarian & .02 \\
Gaya asuhan permisif & \\
Suasana pembelajaran keluarga & $.38^{* *}$ \\
Orientasi pencapaian keluarga & -.02 \\
Orientasi intelektual budaya & \\
Penglibatan keluarga & $.48^{* *}$ \\
Penyertaan ibu bapa & $.31^{* *}$ \\
Sokongan ibu bapa & \\
\hline
\end{tabular}

** signifikan pada paras $\mathrm{p}<.05$

Jadual 1 menunjukkan keputusan analisis korelasi untuk menguji hipotesis mengkaji hubungan signifikan antara faktor keluarga terhadap pembelajaran regulasi kendiri murid sekolah rendah. Nilai pekali korelasi antara penyertaan ibu bapa $(\mathrm{r}=.48, \mathrm{p}<.05)$, orientasi pencapaian keluarga $(\mathrm{r}=.38, \mathrm{p}<.05)$, sokongan ibu bapa $(\mathrm{r}=.32$, $\mathrm{p}<.05)$ mempunyai hubungan positif yang sederhana $(\mathrm{r}=.30-.49)$ terhadap pembelajaran regulasi kendiri manakala gaya asuhan ibu bapa autoritatif $(\mathrm{r}=.26, \mathrm{p}<.05)$, gaya asuhan ibu bapa autoritarian $(\mathrm{r}=.21, \mathrm{p}<.05)$ mempunyai hubungan positif tetapi hubungannya adalah lemah dengan pembelajaran regulasi kendiri pada aras 0.05.

\section{ANALISIS REGRESI BERGANDA KAEDAH STEPWISE}

Dalam kajian ini teknik analisis regresi berganda kaedah stepwise digunakan untuk menjawab objektif mengkaji pengaruh faktor keluarga (gaya asuhan ibu bapa, suasana pembelajaran keluarga dan penglibatan keluarga) terhadap pembelajaran regulasi kendiri murid sekolah rendah. Prosedur penyelesaian stepwise (stepwise solution) merupakan variasi prosedur forward solution. 


\section{PERAMAL FAKTOR KELUARGA TERHADAP PEMBELAJARAN REGULASI KENDIRI}

Hasil analisis regresi berganda dalam Jadual 2(a) dan(b) menunjukkan bahawa lima variabel keluarga dimasukkan dalam model regresi mengikut susunan nilai beta $(\beta)$ yang signifikan. Teknik ini disokong oleh Chua (2009) kerana pengkaji dapat mengesan variabel peramal atau variabel keluarga yang mempengaruhi pembelajaran regulasi kendiri. Dapatan analisis menunjukkan kelima-lima variabel keluarga ini adalah peramal keluarga yang signifikan; penyertaan ibu bapa $(\beta=.354, p<.05)$, orientasi pencapaian keluarga $(\beta=.167$, $\mathrm{p}<.05)$, sokongan ibu bapa $(\beta=.131, \mathrm{p}<.05)$, gaya asuhan tidak responsif $(\beta=.099, p<.05)$ dan gaya asuhan autoritatif $(\beta=.082$, $\mathrm{p}<.05)$. Walau bagaimanapun, gaya asuhan autoritarian, permisif dan orientasi intelektual budaya tidak dimasukkan dalam model regresi. Variabel-variabel peramal tersebut mempunyai nilai beta in (anggaran nilai beta apabila ia dimasukkan ke dalam model regresi pelbagai) yang terlalu kecil, jadi variabel-variabel peramal tersebut disingkirkan daripada model oleh prosedur stepwise (Chua, 2009).

Penyertaan ibu bapa $(\beta=.500, \mathrm{p}<.05)$ sendiri menyumbang secara signifikan sebanyak $25.0 \%\left(\mathrm{R}^{2}=.250\right)$ perubahan varians terhadap pembelajaran regulasi kendiri $[\mathrm{F}(1,558)=185.678$, $\mathrm{p}<.05)$. Kombinasi antara kedua-dua variabel penyertaan ibu bapa $(\beta=.408, \mathrm{p}<.05)$ dan orientasi pencapaian keluarga $(\beta=.183$, $\mathrm{p}<.05)$ menyumbang sebanyak $27.5 \%\left(\mathrm{R}^{2}=.275\right)$ perubahan varians terhadap pembelajaran regulasi kendiri $[\mathrm{F}(2,557)=105.554, \mathrm{p}=<.05]$. Seterusnya, kombinasi antara ketiga-tiga variabel penyertaan ibu bapa $(\beta=.355, \mathrm{p}<.05)$, orientasi pencapaian keluarga $(\beta=.182, \mathrm{p}<.05)$ dan sokongan ibu bapa $(\beta=.129, \mathrm{p}<.05)$ menyumbang sebanyak $28.9 \%\left(\mathrm{R}^{2}=.289\right)$ perubahan varians terhadap pembelajaran regulasi kendiri $[\mathrm{F}(3,556)=75.176, \mathrm{p}=<.05]$. Selanjutnya, kombinasi antara keempat-empat variabel penyertaan ibu bapa $(\beta=.368$, $\mathrm{p}<.05)$, orientasi pencapaian keluarga $(\beta=.189, \mathrm{p}<.05)$, sokongan ibu bapa $(\beta=.129, p<.05)$, gaya asuhan tidak responsif $(\beta=.108$, $\mathrm{p}<.05)$ menyumbang sebanyak $30.0 \%\left(\mathrm{R}^{2}=.300\right)$ perubahan varians terhadap pembelajaran regulasi kendiri $[\mathrm{F}(4,555)=59.439, \mathrm{p}=<.05]$. Kombinasi antara kelima-lima variabel penyertaan ibu bapa $(\beta=.354$, $\mathrm{p}<.05)$, orientasi pencapaian keluarga $(\beta=.167, \mathrm{p}<.05)$, sokongan ibu bapa $(\beta=.131, \mathrm{p}<.05)$, gaya asuhan tidak responsif $(\beta=.099, \mathrm{p}<.05)$ dan gaya asuhan autoritatif $(\beta=.082, \mathrm{p}<.05)$, menyumbang sebanyak $30.6 \%\left(\mathrm{R}^{2}=.306\right)$ perubahan varians terhadap pembelajaran regulasi 
kendiri $[\mathrm{F}(5,554)=48.789, \mathrm{p}=<.05]$. Model regresi berganda P5 (penyertaan ibu bapa, orientasi pencapaian keluarga, sokongan ibu bapa, gaya asuhan tidak responsif dan autoritatif) merupakan model terbaik dalam meramal pembelajaran regulasi kendiri murid sekolah rendah. Justeru, persamaan regresinya dapat ditulis seperti berikut;

$\mathrm{Y}=\alpha+\mathrm{B}_{1} \mathrm{Xpib}+\mathrm{B}_{2} \mathrm{Xopk}+\mathrm{B}_{3} \mathrm{Xsib}+\mathrm{B}_{4} \mathrm{Xgatr}+\mathrm{B}_{5} \mathrm{Xgaf}$

$\mathrm{Y}=1.632+0.258+0.135+0.070+0.84+0.58$

$\alpha=$ pemalar regresi

$\mathrm{B}_{1}=$ pekali regresi bagi penyertaan ibu bapa

$\mathrm{Xpib}=$ penyertaan ibu bapa

$\mathrm{B}_{2}=$ pekali regresi bagi orientasi pencapaian keluarga

Xopk= orientasi pencapaian keluarga

$\mathrm{B}_{3}=$ pekali regresi bagi sokongan ibu bapa

Xsib = sokongan ibu bapa

$\mathrm{B}_{4}=$ pekali regresi bagi gaya asuhan tidak responsif

Xgatr= gaya asuhan tidak responsif

$\mathrm{B}_{5}=$ pekali regresi bagi gaya asuhan autoritatif

$\mathrm{Xgaf}=$ gaya asuhan autoritatif

Hal ini bermakna, model regresi berganda P5 (penyertaan ibu bapa, orientasi pencapaian keluarga, sokongan ibu bapa, gaya asuhan tidak responsif dan autoritatif) merupakan model terbaik dalam meramal pembelajaran regulasi kendiri murid sekolah rendah. Dapatan kajian ini menunjukkan lima variabel keluarga (penyertaan ibu bapa, orientasi pencapaian keluarga, sokongan ibu bapa, gaya asuhan tidak responsif dan autoritatif) secara positif dan mempunyai nilai beta yang signifikan meramal pembelajaran regulasi kendiri.

Jadual 2 (a)

Rumusan Regresi Linear Peramal Faktor Keluarga

\begin{tabular}{ccccccc}
\hline Model & $\mathrm{R}$ & $\mathrm{R}^{2}$ & ${ }^{\Delta} \mathrm{R}^{2}$ & $\mathrm{Df}$ & $\mathrm{F}$ & $\mathrm{Sig}$ \\
\hline $\mathrm{P} 1$ & .500 & .250 & .248 & 1 & 185.678 & .000 \\
& & & & 558 & & \\
$\mathrm{P} 2$ & .524 & .275 & .272 & 2 & 105.554 & .000 \\
& & & 557 & & \\
& & & 559 & & \\
\hline
\end{tabular}




\begin{tabular}{ccccccc}
\hline Model & $\mathrm{R}$ & $\mathrm{R}^{2}$ & ${ }^{\Delta} \mathrm{R}^{2}$ & $\mathrm{Df}$ & $\mathrm{F}$ & $\mathrm{Sig}$ \\
\hline $\mathrm{P} 3$ & .537 & .289 & .285 & 3 & 75.176 & .000 \\
& & & & 556 & & \\
P4 & .548 & .300 & .295 & 4 & 59.439 & .000 \\
& & & & 555 & & \\
P5 & .553 & .306 & .299 & 559 & & \\
& & & & 554 & & \\
& & & & 559 & & \\
Nota:* $p<0.05$ & & & & & &
\end{tabular}

Peramal: (Pemalar), Penyertaan ibu bapa

Peramal: (Pemalar), Penyertaan ibu bapa, Orientasi pencapaian keluarga

Peramal : (Pemalar), Penyertaan ibu bapa, Orientasi pencapaian keluarga,

Sokongan ibu bapa

Peramal : (Pemalar), Penyertaan ibu bapa, Orientasi pencapaian keluarga,

Sokongan ibu bapa

Gaya asuhan tidak responsif

Peramal : (Pemalar), Penyertaan ibu bapa, Orientasi pencapaian keluarga,

Sokongan ibu bapa

Gaya asuhan tidak responsif, Gaya asuhan autoritatif

Variabel bersandar : Pembelajaran regulasi kendiri

Jadual 2 (b)

Nilai Koefisien bagi Peramal Faktor Keluarga

\begin{tabular}{clcccc}
\hline Model & Variabel & B & Std. & Beta & $\mathrm{t}$ \\
& & & Error & & \\
\hline P1 & Pemalar & 2.346 & .112 & & 20.935 \\
& Penyertaan ibu bapa & .364 & .027 & .500 & $13.626^{*}$ \\
& Pemalar & 1.998 & .136 & & 14.727 \\
& Penyertaan ibu bapa, & .297 & .030 & .408 & $9.809 *$ \\
& Orientasi pencapaian keluarga & .148 & .034 & .183 & $4.397^{*}$ \\
P3 & 1.916 & .137 & & 14.002 \\
& Pemalar & .258 & .032 & .355 & $7.984^{*}$ \\
& Penyertaan ibu bapa, & .147 & .033 & .182 & $4.403^{*}$ \\
& Orientasi pencapaian keluarga, & .069 & .021 & .129 & $3.276^{*}$ \\
& Sokongan ibu bapa & 1.712 & .152 & & 11.270 \\
& Pemalar & .268 & .032 & .368 & $8.306^{*}$ \\
& Penyertaan ibu bapa, & .153 & .033 & .189 & $4.612^{*}$ \\
& Orientasi pencapaian keluarga, & .069 & .021 & .129 & $3.284^{*}$ \\
& Sokongan ibu bapa, & .091 & .030 & .108 & $2.998^{*}$ \\
& Gaya asuhan tidak responsif & 1.632 & .156 & & 10.467 \\
P5 & Pemalar & .258 & .033 & .354 & $7.932^{*}$ \\
& Penyertaan ibu bapa, & .135 & .034 & .167 & $3.944^{*}$ \\
& Orientasi pencapaian keluarga, & .070 & .021 & .131 & $3.344 *$ \\
& Sokongan ibu bapa, & .084 & .031 & .099 & $2.750^{*}$ \\
& Gaya asuhan tidak responsif, & .058 & .027 & .082 & $2.152^{*}$ \\
\hline Gaya asuhan autoritatif
\end{tabular}

Variabel bersandar: Pembelajaran regulasi kendiri (PRK)

aras signifikan $p<.05$ 


\section{PERBINCANGAN}

Dapatan kajian menunjukkan bahawa faktor keluarga mempunyai pengaruh yang signifikan terhadap pembelajaran regulasi kendiri. Faktor keluarga iaitu penyertaan ibu bapa, orientasi pencapaian keluarga, sokongan ibu bapa, gaya asuhan tidak responsif, gaya asuhan autoritatif meramal secara signifikan terhadap pembelajaran regulasi kendiri. Kelima-lima variabel keluarga itu menyumbang secara signifikan sebanyak $30.6 \% \quad\left(\mathrm{R}^{2}=.306, p<.05\right)$ perubahan varians terhadap pembelajaran regulasi kendiri. Hasil kajian juga mendapati bahawa gaya asuhan permisif, gaya asuhan autoritarian dan orientasi intelektual budaya tidak memberi sumbangan yang signifikan dalam pembelajaran regulasi kendiri murid-murid sekolah rendah. Dapatan ini selari dengan kajian-kajian lepas (Brody et al., 1999; Christa et al., 2007; Milkie et al., 2004; Steinberg, 1996) yang menunjukkan bahawa penyertaan dan sokongan ibu bapa mampu mempengaruhi pembelajaran anak-anak. Malahan suasana pembelajaran keluarga turut memberikan implikasi positif terhadap pembelajaran anak-anak. Suasana pembelajaran positif mendorong pembelajaran anak-anak (Amnon Lazar et al., 2007; Ashley, 2006; Dzulkarnain Haji Abdul Rahman, 200; Hashami Bohari et al., 1994; Marjoribanks, 1994; Zarinah Arshat, 2001). Di samping itu, hasil kajian Ensminger dan Slu Sarcik (1992), Kanammah dan Ng (2009) dan Amy (1998) juga menyokong dapatan kajian ini yakni, gaya asuhan secara langsung mempengaruhi pembelajaran regulasi kendiri. Hal ini bermakna dalam usaha untuk memupuk pembelajaran regulasi kendiri, peranan yang dimainkan oleh ibu bapa tidak boleh diabaikan. Ibu bapa harus mengambil inisiatif untuk mendidik anak-anak sejak kecil lagi supaya anak-anak dapat mengawal atur pembelajaran di samping lebih berdikari (Premavathy, 2005).

Kajian ini mempunyai beberapa implikasi pendidikan. Secara keseluruhannya, dapatan kajian menunjukkan bahawa faktor keluarga penting dalam pengukuhan tingkah laku pembelajaran yang positif di peringkat sekolah rendah lagi. Penyertaan, sokongan dan gaya asuhan ibu bapa serta orientasi keluarga ke arah pencapaian yang cemerlang mampu meningkatkan lagi pembelajaran regulasi kendiri anak-anak. Melalui rangkaian seperti Persatuan Ibu Bapa dan Guru (PIBG) dan pihak sekolah dapat menekankan kepentingan penyertaan ibu bapa dalam mengatasi masalah pembelajaran anakanak serta meningkatkan lagi kemahiran pembelajaran regulasi 
kendiri mereka (Kementerian Pelajaran Malaysia, 2012). Penyertaan dan sokongan ibu bapa dalam aktiviti-aktiviti pembelajaran anakanak harus dipergiatkan oleh pihak sekolah. Ibu bapa perlu diberi kesedaran dan pengetahuan melalui seminar dan bahan bercetak tentang strategi-strategi yang boleh diambil untuk meningkatkan lagi pembelajaran regulasi kendiri anak-anak mereka.

\section{KESIMPULAN}

Kesimpulannya, faktor keluarga merupakan salah satu landasan untuk menggalakkan pembelajaran regulasi kendiri, khususnya di peringkat sekolah rendah kerana pada peringkat ini anak-anak masih rapat dan bergantung kepada ibu bapa (Azizah Lebai Nordin, 2002). Kajian-kajian lanjutan harus meneroka faktor-faktor lain selain daripada faktor keluarga yang mungkin mempengaruhi pembelajaran regulasi kendiri murid sekolah rendah, misalnya faktor diri seperti efikasi kendiri dan orientasi matlamat (Abdullah, 2010a, 2010b \& Premavathy, 2005) dan faktor sekolah (Chris \& Rosemary, 2004). Dapatan kajian yang menyeluruh dan terperinci dapat membantu para pendidik merangka strategi-strategi berkesan untuk meningkatkan kemahiran pembelajaran regulasi kendiri di peringkat awal lagi. Hal ini selaras aspirasi negara untuk melahirkan modal insan yang proaktif, berdaya saing dan berdikari dalam bidang akademik (Samsilah Roslan, Abdul Majid Isa, Othman Dato Haji Mohamed \& Rohani Ahmad Tarmizi, 2006).

\section{PENGHARGAAN}

Kajian ini dihasilkan dengan sokongan pembiayaan Skim Penyelidikan Siswazah Universiti Penyelidikan (PRGS) (1001/ PGURU/844005), Universiti Sains Malaysia.

\section{BIBLIOGRAFI}

Abdullah, M. N. L. Y. (2010a). Improving self-regulated learning with self-management tool: An empirical study. Pulau Pinang: Universiti Sains Malaysia.

Abdullah, M. N. L. Y. (2010b). Self-regulated learning: Theory and application. Pulau Pinang: Universiti Sains Malaysia. 
Amnon Lazar, Joseph Guttmann, \& Liat Abas. (2007). Parental Authority in Divorced Families. Journal of Divorce \& Remarriage, University of Haifa, Israel, 50(5).

Amy, A. S. (1998). Family context variables and the development of self regulation in college students. Journal of Adolescence, 33 (129), 17-31.

Ashley, R. (2006). Examining the father-child relationship: Intact vs non intact families and child outcomes of academic performance, conduct and self-esteem. Father-Child Relationship, Honover College, 1-13.

Azizah Lebai Nordin. (2002). Pendidikan awal kanak-kanak: Teori dan amali. Kuala Lumpur: Universiti Malaya.

Ballantine, J. H. (1997). The sociology of education; a systematic analysis, second edition. New Jersey: Prentice Hall.

Bandura, A. (1977). A Social cognitive theory of personality. Dalam L. Pervin \& O. John. (Ed.), Handbook of personality. New York: Guilford Publications.

Bandura, A. (1986). Social foundations of thought and action: A social cognitive theory. New York: Prentice Hall.

Baumrind, D. (1971). Current patterns of authority. Developmental Psychology Monographs, 4(1), 2.

Baumrind, D. (1991). The influence of parenting style on adolescent competence and substance use. Journal of Early Adolescence, 11(1), 56-95.

Brody, G. H., Flor, D. L., \& Gibson, N. M. (1999). Linking maternal efficacy beliefs, developmental goals, parenting practices, and child competence in rural single-parent African American Families. Child Development, 70, 1197-1208.

Buri, J. R. (1991). Parental authority questionnaire, DOI: 10.1207/S 15. Journal of Personality Assessment, 57(1), 110-119.

Chris, J., \& Rosemary, H. (2004). Young children's emergent selfregulated learning skills in a primary science investigation Paper presented at the NZARE Conference, Turning the Kaleidoscope. from http://www.nzcer.org.nz/pdfs/13891.pdf Christa, L. G., Joan, M. T. W., Kathleen, V. H.-D., \& Howard, M. S. (2007). Parent's Motivations for Involment in Children's Education: An Empirical Test of a Theoretical model of Parental Involment Journal of Educational Psychology, 99(3), 532-544.

Chua, Y. P. (2009). Kaedah penyelidikan (Buku5). Malaysia: Mc Graw Hill. 
Dzulkarnain Haji Abdul Rahman. (2003). Pengaruh budaya ibu bapa, rakan sebaya, masyarakat dan sekolah dalam pembentukan disiplin pelajar. Tesis Doktor Falsafah, Yang Tidak Diterbitkan. Universiti Kebangsaan Malaysia, Bangi.

Ensminger, M. E., \& Slusarcick, A. L. (1992). Paths to high school graduation or dropout: A longitudinal study of a first-grade cohort. Sociology of Education, 65, 95-113.

Gay, L. R., \& Airasian, P. (2003). Educational research: Competencies for analysis and applications. Columbus Chio, New Jersey: Upper Saddle River, Merrill Prentice Hall.

Grolilnick, Ryan, \& Deci. (1991). The inner resources for school performance: motivational mediators of children's perceptions of their parents. Journal of Educational Psychology, 83, 508517.

Hashami Bohari, Ezaddin Mohamed, Osman Ali., \& Sharif, M. A. (1994). Masalah pembelajaran murid dari keluarga bercerai. Jurnal Pembangunan Sumber Manusia, 74-79.

Huang, J., \& Prochner, L. (2004). Chinese parenting styles and children's self regulated learning. Journal Article Excerpt Retrieved 22 Mac, 2004, from http://www.eric.ed.go

Kanammah Manukaram, \& Ng , L. Y. A. (2009, January). Selfregulated learner from broken homes: A preliminary study on school children. Paper presented at the International Counseling and Social Work Symposium, Universiti Sains Malaysia, Penang.

Kementerian Pelajaran Malaysia. (2012, September 12). Sebelas anjakan ubah sistem pendidikan Pelan Pembangunan Pendidikan Malaysia 2013-2025. Berita Harian, p. 1-11.

Marjoribanks, K. (1994). Families, school and children's learning environments. International Journal of Educational Research, 21, 439-555.

Milkie, M. A., Mattingly, M. J., Namaguchi, K. M., Bianchi, S. M., \& Robinson, J. P. (2004). The time squeeze: Parental statuses and feelings about time with children. Journal of Marriage and Family, 66, 739-761.

Mohd Majid Konting. (1990). Kaedah penyelidikan pendidikan. Kuala Lumpur: Dewan Bahasa dan Pustaka.

Mok, S. S. (2009). Psikologi pendidikan. Subang Jaya: Kumpulan Budiman Sdn.Bhd.

Moos, R. H., \& Moos, B. (1974). Family environment scale. Palo Alto CA: Consulting Psychologists Press. 
Murugiah Velayutham. (1997). Psikologi pendidikan:Psikologi perkembangan. Kuala Lumpur: Kumpulan Budiman Sdn. Bhd.

Ng, L. Y. A. (3-5 Sept 2007b). Children's beliefs about intelligence: A mixed method study. Paper presented at the Refereed proceedings in the 4th international Qualitative research convention Malaysia (QRAM): Doing qualitative research, processes, issues, and challenges, Selangor, Malaysia.

Pintrich, P. R., Smith, D. A. F., Garcia, T., \& Mckeachie, W. J. (1991). A manual for the use of the motivated strategies for learning Questionnaire (MSLQ). University of Michigan: National Center for Research to Improve Postsecondary Teaching and Learning.

Pintrich, P. R. (1999). The role of motivation in promoting and sustaining self- regulated learning. International Journal of Educational Research, 31, 459-470.

Pintrich, P. R. (2004). A conceptual framework for assessing motivation and self regulated learning in college student. Educational Psychology Review, 16(4), 385-407.

Premavathy Ponnusamy. (2005). The Influence of self-regulated learning tendency, achievement goal orientation, class and gender on academic help-seeking behavior among form four students (Unpublished Idoctoral dissertation). Universiti Sains Malaysia, Pulau Pinang

Rohaty Mohd Majzub, T.Subahan Mohd Meerah Ahmad, \& Jaffni Hassan. (1994). Pembangunan sumber manusia. Bangi: Universiti Kebangsaan Malaysia.

Samsilah Roslan. (2000). Hubungan antara pembelajaran aturan kendiri dan keyakinan terhadap kebolehan diri dengan pencapaian akademik di kalangan pelajar di institusi pengajian tinggi. Tesis Doktor Falsafah Yang Tidak Diterbitkan. Universiti Putra Malaysia, Serdang.

Samsilah Roslan, Abdul Majid Isa, Othman dato Haji Mohamed, \& Rohani Ahmad Tarmizi. (2006). Hubungan orientasi matlamat dengan penggunaan strategi pembelajaran regulasi kendiri. Jurnal Pendidikan, Univesiti Malaya, 113.

Sharifah Amnah Syed Ahmad. (2008). Sumbangan peramal kognitif dan bukan kognitif terhadap pencapaian akademik dalam kalangan pelajar di sebuah institusi pengajian tinggi awam. Tesis Doktor Falsafah, Yang Tidak Diterbitkan. Universiti Sains Malaysia, Puau Pinang. 
Sheridan, J. C., Lyndall, S., \& Clara, O. (2010). Analysis without anguish: SPSS version 17.0 for windows. Australia: John Wiley \& Australia, Ltd.

Steinberg, L. (1996). Beyond the classroom: Why school reform has failed and what parents need to do. New York: Simon \& Schuster.

Syed Anwar Aly, \& Merza Abbas. (2000). Penyerapan kemahiran saintifik dalam proses pengajaran dan pembelajaran kimia di tahap menengah. . Paper presented at the UiTM Seminar for Science and Mathematics Education, October 2-3, Shah Alam.

Uma Sekaran. (2003). Research methods for business: A skill building approach (4th ed.). New York: John Wiley \& Sons.

Zarinah Arshat. (2001). Kualiti persekitaran sosial keluarga dan pencapaian akademik anak. Jurnal Pembangunan Sosial (Jun) 2, 161-184.

Zimmerman, B. J. (1989a). A social cognitive view of self -regulated academic learning. Journal of Educational Psychology, 81(3), 329-339.

Zimmerman, B. J. (1989b). Model of self-regulated learning and academic achievement. Dalam B.J. Zimmerman \& D.H Schunk (Eds), Self-regulated learning and academic achievement: Theory, research and practice, progress in cognitive development research. New York: Springer-Verlag.

Zimmerman, B. J. (2002). Becoming a self- regulated learner: an overview. Theory into practice. Journal of Educational Psychology, 41(2), 64-70. 
